\title{
Interest Premium, Sudden Stop, and Adjustment in a Small Open
}

\section{Economy}

\author{
Peter Benczur and Istvan Konya ${ }^{+}$
}

2016 May

\begin{abstract}
We study the adjustment process of a small open economy to a sudden worsening of external conditions. To model the sudden stop, we use a highly non-linear specification that captures credit constraints in a convenient way. The advantage of our approach is that the effects of the shock become highly conditional on the external debt position of the economy. We adopt a two-sector model with money-in-the-utility, which allows us to study sectoral asymmetries in the adjustment process, and also the role of currency mismatch. We calibrate the model to the behavior of the Hungarian economy in the 2000 s and its crisis experience in 2008-11 in particular. We also calculate four counterfactuals: two with different exchange rate policies (a more flexible float and a perfect peg), and then these two policy regimes with smaller initial indebtedness. Overall, our model is able to fit movements of key aggregate and sectoral macroeconomic variables after the crisis by producing a large and protracted deleveraging process. It also offers a meaningful quantification of the policy tradeoff between facilitating the real adjustment by letting the currency depreciate and protecting consumption expenditures by limiting the adverse effect of exchange rate movements on household balance sheets.
\end{abstract}

Keywords: interest premium, sudden stop, small open economy.

JEL Codes: E21, E41, E5, F3

\footnotetext{
*European Commission, Joint Research Centre (JRC). Benczur is also a Research Associate at the Institute of Economics, Centre for Economic and Regional Studies of the Hungarian Academy of Sciences, and Central European University.

${ }^{\dagger}$ Centre for Economic and Regional Studies of the Hungarian Academy of Sciences and Central European University. Corresponding author, konyai@ceu.hu.
} 


\section{Introduction}

The "crisis of 2008" is the biggest and most widespread recession since the Great Depression. While the crisis originated in the United States, it quickly spread to other advanced and emerging economies. Although in the US the main problem was the near collapse of financial intermediation, in many small emerging economies the key feature of the recession was a sudden worsening of external credit conditions. Taking such a shift in the external financing premium as given, our goal is to study the quantitative effects of such an exogenous shock using a small open economy model.

An important aspect of the crisis was that emerging economies, and countries in Central and Eastern Europe in particular, have built up significant unhedged foreign currency liabilities before the 2008 crisis (currency mismatch). A sudden tightening of external borrowing terms decreases the demand for local currency, putting nominal exchange rates under pressure. Normally, such a depreciation facilitates the adjustment of the economy, by allowing tradable prices and production costs (real wages) to fall. In contrast, under a currency mismatch, there is an important tradeoff: the resulting depreciation severely weakens the balance sheets (foreign currency value of net wealth) of almost all economic actors (households, firms and the government) in such countries, amplifying the impact of the crisis. In the CEE region, central banks in mismatch countries were indeed defending their exchange rates both by interest rate hikes and interventions, in order to limit the deterioration of balance sheets (for Hungary, see Gereben, Karvalits and Kocsis, 2011).

Figure 1 plots the maximum increase in CDS spreads after the third quarter of 2008 against the net foreign asset position for a set of Central and Eastern European (CEE) countries. The figure demonstrates very clearly our primary motivation: the starting external position of these countries determined the severity of the external premium shock during the financial crisis. Figure 2 shows that foreign currency lending was indeed prevalent in Hungary, Romania and to a lesser extent in Poland. ${ }^{1}$ Not coincidentally, and consistent with our modeling assumptions, more heavily indebted countries relied more on foreign currency financing.

Within this context, we seek answers to the following questions. Can we capture the large and persistent impact of the crisis on small open economies with a single shock to foreign borrowing conditions? How do the effects depend on the external debt position of this economy? Can and should the central bank alleviate the real effects by manipulating the nominal exchange rate? How does the exchange rate

\footnotetext{
${ }^{1}$ Slovenia was already on the euro in 2008. Though Bulgaria also had a large share of euro loans, the country had a hard peg to the euro.
} 


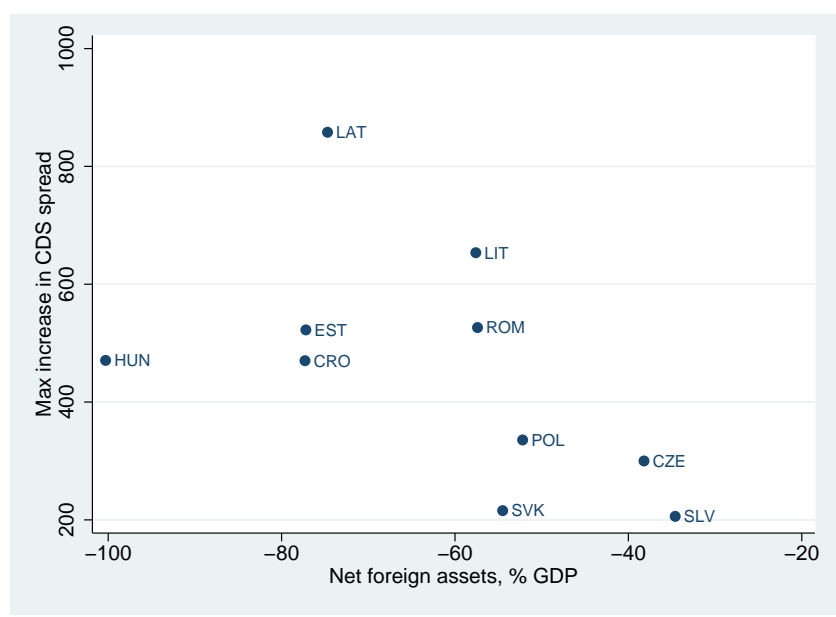

Figure 1: Initial debt and CDS increase in the crisis



Figure 2: Foreign currency debt

policy tradeoff depend on currency mismatch?

To answer these questions, we build a quantitative two-sector small open economy model with endogenous currency mismatch through foreign currency borrowing and money in the utility. The role of the latter is to provide a (reduced form) rational for households to hold domestic currency denominated assets. We assume that foreign borrowing has to be in foreign currency, and the interest rate is dependent on the indebtedness of the economy. The main shock we are interested in is a permanent tightening of external credit conditions, implemented as a shift in the foreign interest premium function. Technically, we look at the long-run effects of a permanent, unexpected shock (a transition from an initial to a new steady state). ${ }^{2}$

\footnotetext{
${ }^{2}$ In order to match the initial developments in Hungary and the CEE region, we add a second, one period shock that captures the large drop in foreign demand. While this may ultimately be caused by the same world-wide tightening of credit conditions, in our small open economy setting it is sufficient to implement it as a decline in foreign demand. Since this shock lasts only for one period, it plays essentially no role in the persistence of the effects of the crisis in our model economy, which is solely
} 
We calibrate the model to fit important aggregate and sectoral aspects of the Hungarian economy. Then we introduce the shocks of 2008 by an export demand shock and a change in the parameters of the external premium function (a large decline in the neutral level of the net foreign asset position), fitting exchange rate, interest rate and tradable output changes. Overall, we judge the model's ability to fit key macroeconomic variables to be very good: all variables move in the expected direction, and the magnitudes are also reasonable. In particular, in response to an initial increase of 485 basis points in the external premium, consumption expenditures fall by $17 \%$, investment falls by $46 \%$, the nontradedtraded relative price falls by $19.5 \%$, and they do not completely recover for more than a decade. Though these numbers are larger than the initial drops we observed in Hungary, the three-year cumulative impacts are quite similar.

Then we do four counterfactual experiments, which give us the following results. (i) Under more exchange rate flexibility, our model is capable to generate both the advantages and the disadvantages of a "competitive devaluation". The export sector declines less on impact, and booms more after the export demand shock passes, but household balance sheets suffer more, due to a large depreciation of the exchange rate and a massive capital loss on foreign loans. (ii) Fixing the exchange rate protects households from the impact of the currency mismatch, but at the cost of a deeper drop in exports and employment (mostly because the nominal wage cannot decrease enough due to downward nominal rigidity). Based on this, we find that letting the exchange rate float more freely would have been undesirable for the Hungarian economy. The tradeoffs between export performance and consumption expenditures called for a muted exchange rate depreciation. (iii) Lower initial indebtedness allows the country to smooth consumption more by borrowing from abroad, despite the increase in the interest premium. A less indebted economy suffers less in the crisis, at least in terms of consumption decline. The relative performance of the two exchange rate regimes also changes: we find that increased exchange rate flexibility would have been beneficial, had Hungary been less indebted in 2008.

An important methodological contribution of our paper is the adoption of a highly nonlinear and asymmetric specification for the interest premium function. Since we are interested in the response of the economy to a small number of large shocks, we can solve the model nonlinearly, without a need for approximation. This allows us to study the effects of the crisis conditional on the external debt position of our model economy, in a tractable and parsimonious way.

This novel specification of the external finance premium leads to a strong international transmission explained by the permanent shock to foreign borrowing conditions. 
of shocks through financial markets (like in Devereux and Yetman, 2010), and resembles more complex frameworks of occasionally binding credit constraints (like Mendoza, 2010) in three important aspects: (i) a near-constant interest rate when net foreign assets are positive, (ii) a quickly rising premium for large debt holdings, and (iii) the (almost) existence of an absolute borrowing constraint. ${ }^{3}$ These features make our model economy's net foreign asset per GDP ratio consistent with observed time series and cross section patterns: this ratio can vary substantially across countries and in time, with high persistence, within a wide yet bounded range (see for example Lane and Milesi-Ferretti, 2007). When net foreign assets are positive or slightly negative, the implied interest premium is small and there is only a weak force keeping the external position within bounds. When they become highly negative, the interest premium increases strongly, driving external imbalances back to normal. This framework also merges the small debt elasticity calibration of Schmitt-Grohe and Uribe (2003) and the much larger elasticity estimates of Garcia-Cicco et al (2010).

We then link the impact of the external financing shock to the exchange rate regime of the country. Existing models (for example, Gertler, Gilchrist and Natalucci, 2007, or Faia, 2010) usually quantify the welfare costs of the constraint that a pegged regime puts on the response of an economy to such a shock: on the one hand, flexible exchange rates allow a quicker nominal adjustment in case of nominal frictions (price or wage stickiness); and on the other hand, in order to defend the exchange rate, the central bank has to raise interest rates, which -- through financial frictions -- exacerbates the initial output loss. In case of domestic (or a mix of domestic and foreign) shocks, however, Faia (2010) finds that a peg can allow a softer reaction of the interest rate, hence a smaller output response. We, on the other hand, want to explore the tradeoff between letting the currency depreciate and allowing for a quicker real adjustment of the economy, versus protecting consumption expenditures by limiting exchange rate movements and saving household balance sheets. Our results show that a peg (or a managed float) can indeed perform better even in case of purely external shocks.

We describe the model in detail later, but the main intuition is as follows. The increase in the interest premium makes households poorer, and its also makes foreign debt more costly. Households respond by paying back debt through reducing consumption, working more, and decreasing their money demand. There is also an investment decline, due to higher borrowing costs. In response to the decrease in export demand, employment in the export sector decreases, while households borrow more to smooth

\footnotetext{
${ }^{3}$ These properties make it very similar to the penalty function approach of Judd (1998), advocated recently by De Wind (2008) and Den Haan and Ocaktan (2009).
} 
consumption and work less due to lower labor demand and hence lower wages. The initial net effect in the short run depends on the strength of these often opposing effects, but after the first period the interest premium shock drives the economy.

Depending on the exchange rate regime, the money market clears in different ways, which has important implications for the real economy. When the exchange rate is flexible, it depreciates to match the reduced demand for the fixed nominal supply of money. The lower exchange rate, in turn, stimulates exports, and dampens the effect of the export demand shock. Consumption falls, however, since the lower exchange rate increases the indebtedness of the economy measured in foreign currency (tradables).

When the exchange rate is fixed, the export sector cannot take advantage of a weaker currency, hence exports and employment fall more. This is particularly severe under downward nominal wage rigidity, which we allow for. Households, on the other hand, can use their money holdings to pay back foreign debt at the fixed exchange rate, and hence their balance sheet remains in a better shape. This, in turn, implies that consumption declines less than under a flexible exchange rate. One of our main goals is to quantitatively evaluate the links between export performance, consumption, currency mismatch, and the exchange rate regime.

The paper is organized as follows. The next section describes the model. Section 3 presents our quantitative exercise: model calibration, the impact of the crisis, and the three counterfactual scenarios. Finally, Section 4 concludes.

\section{The model}

To understand the impact of the crisis, we build a two-sector small open economy model, based on the approach in Benczur and Konya (2013). The economy produces non-tradables and exports, while non-tradables and imports are used for consumption and investment. Households consume, invest into physical capital, supply labor, and allocate their financial assets between foreign bonds and domestic money holdings. Households pay an interest premium on foreign bonds, which depends on the indebtedness of the country as in Schmitt-Grohé and Uribe (2003), and hence taken as exogenous by households. Money is valued because it enters directly into the utility function.

Our goal is to have a framework with currency mismatch, non-linearity in the finance premium, and slow adjustment of real variables. As we show later, money-in-the-utility generates currency mismatch. 
The deterministic framework and the particular specification of the foreign interest premium allows for highly non-linear effects from foreign borrowing. Slow adjustment on the real side comes from investment adjustment costs at the sectoral level.

\subsection{Related literature}

There are many other studies that employ quantitative small open economy models to understand the effects of various external shocks. Fernandez de Cordoba and Kehoe (2000), and Bems and Hartelius (2006) use a two-sector real model to study the current account and real exchange rate implications of trade and financial opening. Rebelo and Végh (1995) and Burstein, Eichenbaum and Rebelo (2007) add a nominal side by introducing money. Apart from the different question (Rebelo and Végh (1995) look at exchange rate based stabilizations, while Burstein, Eichenbaum and Rebelo (2007) study exchange rate pass-through under large devaluations), our model differs in several aspects. In our framework, money does not have a direct role through a transaction technology, a feature both of their models exhibit. Burstein, Eichenbaum and Rebelo (2007) also assume price rigidity, while we have totally flexible prices. Even more importantly, our model has an external interest premium, so it can be used to analyze the role of credit conditions. Finally, Cook and Devereux (2006), Gertler, Gilchrist and Natalucci (2007), Brzoza-Brzezina and Makarski (2011) and Heer and Schubert (2012) all have financing frictions and risk premium shocks, but they do not consider the implications of a currency mismatch in external positions.

Our model extends our previous work (Benczur and Konya,2013). In that paper, the main goal is to understand the impact of the exchange rate regime on capital accumulation during convergence. Here, on the other hand, we look at countries that experience external shocks and move from one steady state to the next. We also modify the Benczur and Konya (2013) model in three aspects. (i) We add a downward sloping export demand curve, which allows us to add an export demand shock. (ii) We introduce a monetary policy rule that accommodates interim exchange rate regimes ("dirty floating", as opposed to a pure float or a fixed exchange rate regime). (iii) And finally, we assume that the external premium depends on the net foreign asset position of households, instead of the consolidated position of the country itself (which would also include central bank reserves).

This latter assumption is the main channel for the impact of currency mismatch. In Benczur and Konya (2013), the mechanism is that the central bank earns a lower interest rate on reserves than what households pay on foreign debt, hence holding the domestic currency asset (which has to be backed by foreign exchange reserves) has a real effect on the economy. In our current model, while a depreciation 
in general leads to a capital loss of households, it also implies a nearly offsetting capital gain at the central bank. But due to our external premium specification, even if this gain is redistributed to households, there is still a worsening in the external premium, impacting the real economy. In other words, repaying foreign currency debt from local currency assets is not neutral: although there is a corresponding decline in central bank reserves, the external financing premium still declines. Note that while we make a strong assumption, the mechanism operates as long as central bank reserves and foreign debt are not perfect substitutes.

\subsection{Production}

Final composite investment and consumption goods are assembled from imported (M) and non-tradable (N) intermediate inputs. Export goods and non-tradables are produced domestically using capital and labor. Note that, following Burstein, Eichenbaum and Rebelo (2007), we assume that domestically produced tradables are exported (X), while tradables used in consumption and investment are imported. Capital is specific to a sector, and investment is subject to adjustment costs (see below at the household section). We use this assumption to prevent large reallocations across sectors; a similar assumption was used in Bems and Hartelius (2006).

\subsubsection{Final goods}

Investment in sectors $\mathrm{X}$ and $\mathrm{N}$ and final consumption are aggregates of imported and non-tradable goods, and are assembled by competitive firms using Cobb-Douglas technologies. When describing the production technology for investment, it is important to account for the quadratic adjustment costs. Using $I_{j, t}$ for investment in sector $j$ net of adjustment costs and $C_{t}$ for consumption, we can write the production functions as follows: ${ }^{4}$

$$
\begin{aligned}
C_{t} & =\lambda^{-\lambda}(1-\lambda)^{\lambda-1}\left(C_{t}^{M}\right)^{\lambda}\left(C_{t}^{N}\right)^{1-\lambda} \\
\left(1+\frac{\phi}{2} \frac{I_{j, t}}{K_{j, t-1}}\right) I_{j, t} & =\lambda_{I}^{-\lambda_{I}}\left(1-\lambda_{I}\right)^{\lambda_{I}-1}\left(I_{j, t}^{M}\right)^{\lambda_{I}}\left(I_{j, t}^{N}\right)^{1-\lambda_{I}},
\end{aligned}
$$

where $\phi$ measures the extent of investment adjustment costs. Because we lack data on the tradable intensity of investment at the sectoral level, we assume that this intensity is not sector specific $\left(\lambda_{I}\right)$.

\footnotetext{
${ }^{4}$ Note that the subscript $j$ indexes investment targeted towards the accumulation of capital in sector $j=X, N T$, while the superscripts indicate the tradable $(\mathrm{M})$ and non-tradable components of these investments.
} 
Cost-minimization and free entry (zero profits) can be used to calculate the demand functions for the imported and non-tradable components of consumption and investment, and the price indexes for the final goods. We assume that only imported tradables are used in consumption and investment, as in Burstein, Eichenbaum and Rebelo (2007). The law of one price holds for import goods, and we normalize the foreign importable price to unity, so that $P_{t}^{M}=S_{t}$, where $S_{t}$ is the nominal exchange rate. Demand for imports and non-tradables in consumption and investment can be written as:

$$
\begin{aligned}
S_{t} C_{t}^{M} & =\lambda P_{t}^{C} C_{t} \\
P_{t}^{N} C_{t}^{N} & =(1-\lambda) P_{t}^{C} C_{t} \\
S_{t} I_{j, t}^{T} & =\lambda_{I} P_{t}^{I}\left(1+\frac{\phi}{2} \frac{I_{j, t}}{K_{j, t-1}}\right) I_{j, t} \\
P_{t}^{N} I_{j, t}^{N} & =\left(1-\lambda_{I}\right) P_{t}^{I}\left(1+\frac{\phi}{2} \frac{I_{j, t}}{K_{j, t-1}}\right) I_{j, t} .
\end{aligned}
$$

The price indexes for consumption and investment are given by:

$$
\begin{aligned}
& P_{t}^{C}=S_{t}^{\lambda}\left(P_{t}^{N}\right)^{1-\lambda} \\
& P_{t}^{I}=S_{t}^{\lambda_{I}}\left(P_{t}^{N}\right)^{1-\lambda_{I}} .
\end{aligned}
$$

\subsubsection{Intermediate goods}

Exports and non-tradables are produced using capital and labor. The production functions in both sectors are Cobb-Douglas:

$$
Y_{t}^{j}=K_{j, t}^{\alpha_{j}} N_{j, t}^{1-\alpha_{j}}
$$

where $N_{j, t}$ is labor employed in sector $j$, and $K_{j, t}$ is capital used in sector $j$.

Firms maximize profits, subject to factor prices $W_{t}$ and $r_{j, t}^{k}$ (measured in domestic currency):

$$
\max _{K_{j, t}, N_{j, t}}\left\{P_{t}^{j} K_{j, t}^{\alpha_{j}} N_{j, t}^{1-\alpha_{j}}-r_{j, t}^{k} K_{j, t}-W_{t} N_{j, t}\right\}
$$


The first-order conditions of the problem are given by

$$
\begin{aligned}
r_{j, t}^{k} & =P_{t}^{j} \alpha_{j}\left(\frac{K_{j, t}}{N_{j, t}}\right)^{\alpha_{j}-1} \\
W_{t} & =P_{t}^{j}\left(1-\alpha_{j}\right)\left(\frac{K_{j, t}}{N_{j, t}}\right)^{\alpha_{j}} .
\end{aligned}
$$

\subsection{Households}

There is a range of households with measure 1 in the economy. Households can hold three types of assets: capital, interest bearing foreign bonds and non interest bearing domestic money. We assume that domestic money is not accepted by the rest of the world. For accounting purposes we also introduce nominal bonds $D_{t}$, which households use to acquire cash from the central bank. As in chapter 5 of Végh (2013), and without loss of generality, we assume that they do not pay interest. ${ }^{5}$ These bonds may or may not be accepted by the monetary authority, depending on the currency regime. Because they bear no interest, households want to sell as much as the central bank is willing to accept. We relegate the detailed description of monetary policy to a later section.

Households draw income from (i) supplying labor, (ii) renting out capital to firms, and (iii) holding foreign bonds and domestic money. They allocate some of their income towards consumption and investment, and carry the remaining amount over to the next period in terms of financial assets. Although money does not pay interest, it is valued by households as it enters the utility function directly (moneyin-the-utility). It can also yield a financial return in case of an exchange rate appreciation. Households can freely adjust their portfolios between money and bonds within a period. In addition, households accumulate capital for both the export and non-tradable sectors. As discussed above, investment is subject to quadratic adjustment costs.

Households are monopolistic suppliers of differentiated labor services $N_{i, t}$, as in Erceg, Henderson and Levin (2000). Firms use a CES labor aggregate of individual varieties for production, subject to wages set by households

$$
N_{t}=\left[\int_{0}^{1} N_{i, t}^{1-\frac{1}{\sigma_{w}}} d i\right]^{\frac{\sigma_{w}}{\sigma_{w}-1}} .
$$

We follow Fahr and Smets (2010) in their specification of the wage adjustment function, which allows us to incorporate downward nominal wage rigidity (DNWR) in the analysis. Changing wages is subject to a utility cost $\Gamma\left(W_{i, t} / W_{i, t-1}\right)$, where the adjustment cost function is highly asymmetric. We return

\footnotetext{
${ }^{5} \mathrm{Any}$ interest revenue would be rebated to households by the central bank.
} 
to the wage setting decision in the next section.

Household $i$ thus solves the following problem:

$$
\max \sum_{t=0}^{\infty} \beta^{t}\left[\log C_{i, t}+\gamma \log \frac{H_{i, t}}{P_{t}}-\chi \frac{N_{i, t}^{1+\omega}}{1+\omega}-\Gamma\left(\frac{W_{i, t}}{W_{i, t-1}}\right)\right]
$$

s.t. $\quad S_{t}\left(B_{i, t}-R_{t-1} B_{i, t-1}\right)+H_{i, t}-H_{i, t-1}-D_{i, t}+D_{i, t-1}=W_{i, t} N_{i, t}+\sum_{j=X, T} r_{j, t}^{k} K_{i j, t-1}-P_{t} C_{i, t}-$

$$
\begin{aligned}
& -P_{t}^{I} \sum_{j=X, N}\left(1+\frac{\phi}{2} \frac{I_{i j, t}}{K_{i j, t-1}}\right) I_{i j, t}+T_{i, t} \\
K_{i j, t} & =(1-\delta) K_{i j, t-1}+I_{i j, t},
\end{aligned}
$$

where $R_{t}$ is the discount rate on foreign currency denominated bonds $B_{i t}, H_{i t}$ is the stock of domestic money, and $N_{i t}$ is the household's labor supply.

After some simplification, the first-order conditions -- apart from the wage setting decision -- are written as follows:

$$
\begin{aligned}
\frac{\left(P_{t+1} / S_{t+1}\right) C_{i, t+1}}{\left(P_{t} / S_{t}\right) C_{i, t}} & =\beta R_{t} \\
\frac{\gamma}{H_{i, t}} & =\frac{1}{P_{t} C_{i, t}}-\frac{\beta}{P_{t+1} C_{i, t+1}} \\
Q_{i j, t} & =1+\phi \frac{I_{i j, t}}{K_{i j, t-1}} \\
Q_{i j, t} & =\frac{P_{t+1}^{I} / S_{t+1}}{P_{t}^{I} / S_{t}}\left[\frac{r_{j, t+1}^{k}}{P_{t+1}^{I}}+(1-\delta) Q_{i j, t+1}+\frac{\phi}{2}\left(\frac{I_{i j, t+1}}{K_{i j, t}}\right)^{2}\right] \frac{1}{R_{t}} \\
K_{i j, t} & =(1-\delta) K_{i j, t-1}+I_{i j, t} .
\end{aligned}
$$

The first equation is the consumption Euler equation, the second is money demand, the third is the investment equation where $q_{j, t}$ is Tobin's $\mathbf{q}$, the fourth is the arbitrage condition between investment and bonds, and the last is the capital accumulation equation (restated for convenience). Note that the last three equations must hold separately for $j=X, N$. 


\subsubsection{Wage setting}

Household $i$ sets the wage rate for its specialized labor services subject to the usual CES demand function from (8):

$$
N_{i, t}=\frac{W_{i, t}^{-\sigma_{w}}}{W_{t}^{-\sigma_{w}}} N_{t}
$$

Using this demand function, and substituting in the first-order condition for consumption, the wage setting problem is given by the following:

$$
\max \sum_{t=0}^{\infty} \beta\left[\frac{1}{P_{t}} \xi_{i, t} W_{i, t}^{1-\sigma_{w}} \frac{N_{t}}{W_{t}^{-\sigma_{w}}}-\chi \frac{\left(W_{i, t}^{-\sigma_{w}} N_{t} / W_{t}^{-\sigma_{w}}\right)^{1+\omega}}{1+\omega}-\Gamma\left(\frac{W_{i, t}}{W_{i, t-1}}\right)\right.
$$

s.t. $\Gamma\left(\frac{W_{i, t}}{W_{i, t-1}}\right)=\frac{\nu_{w}-1}{2}\left(\frac{W_{i, t}}{W_{t-1}}-1\right)^{2}+\frac{\exp \left[-\zeta\left(W_{i, t} / W_{i, t-1}-1\right)\right]+\zeta\left(W_{i, t} / W_{i, t-1}-1\right)-1}{\zeta^{2}}$, (14)

where $\xi_{i t}=1 / C_{i, t}$ is the marginal utility of consumption. The adjustment cost function $\Gamma$ takes the Linex form used in Fahr and Smets (2010), and is capable of approximating DNWR to an arbitrary precision. The Appendix plots $\Gamma(\cdot)$ with our parameterization that we discuss in the calibration section.

The first-order conditions are given by the following equations:

$$
\frac{W_{i, t}}{W_{i, t-1}} \Gamma^{\prime}\left(\frac{W_{i, t}}{W_{i, t-1}}\right)=\left(1-\sigma_{w}\right) \frac{W_{i, t}}{P_{t}} N_{i, t} \xi_{i, t}+\chi \sigma_{w} N_{i, t}^{1+\varphi}+\beta \frac{W_{i, t+1}}{W_{i, t}} \Gamma^{\prime}\left(\frac{W_{i, t+1}}{W_{i, t}}\right),
$$

where

$$
\Gamma^{\prime}\left(\frac{W_{i, t}}{W_{i, t-1}}\right)=\left(\nu_{w}-1\right)\left(\frac{W_{i, t}}{W_{i, t-1}}-1\right)+\frac{1-\exp \left[-\zeta\left(\frac{W_{i, t}}{W_{i, t-1}}-1\right)\right]}{\zeta} .
$$

Because households are identical ex ante, they will all set the same wage $W_{t}$. This implies that all other decisions are completely symmetric as well, and aggregation across households is trivial. In what follows we omit the subscript $i$, as all household variables will refer to aggregate measures.

\subsection{The central bank}

We follow Végh (2013) in our description of the central bank balance sheet and in the definitions of a floating currency regime and a currency board. We assume that central bank assets include foreign currency $b_{t}^{c}$ and domestic non-interest bearing bonds $D_{t}$ issued by households. ${ }^{6}$ The per period budget

\footnotetext{
${ }^{6}$ Central banks could and do hold interest bearing foreign assets. In the crisis period, however, interest earned on safe foreign assets -- such as US or German government securities -- was essentially zero. We thus do not distinguish between
} 
constraint of the central bank is then given by:

$$
S_{t}\left(b_{t}^{c}-b_{t-1}^{c}\right)+D_{t}-D_{t-1}+T_{t}=H_{t}-H_{t-1}
$$

The monetary policy regime is characterized by two parameters, $\rho_{s}$ and $\rho_{h}$. First, we posit the following policy rule:

$$
\left(\frac{H_{t}}{H_{t-1}}\right)^{\rho_{s}}\left(\frac{S_{t}}{S_{t-1}}\right)^{1-\rho_{s}}=1
$$

At one extreme $\left(\rho_{s}=0\right)$, the central bank follows a fixed exchange rate rule and accommodates changes in the money demand by changes in its foreign reserves. At the other extreme $\left(\rho_{s}=1\right)$, the money supply is fixed and the exchange rate is floating. Intermediate values of $\rho_{s}$ indicate the extent of the central bank's desire to keep the exchange rate stable.

The central bank keeps foreign reserves to provide foreign currency liquidity when the currency does not freely float. The following equation describes the extent of foreign reserve holdings:

$$
b_{t}^{c}=\rho_{h} \frac{H_{t}}{S_{t}} .
$$

Under a pure float, $\rho_{h}=0$, while under a currency board, $\rho_{h}=1$. In our baseline we track the actual reserve to money developments in Hungary, including a significant increase during the crisis. In counterfactual experiments we choose reserve paths in line with the corresponding hypothetical exchange rate regime. We discuss the precise choice of parameter values in section 3.1.

Note that the monetary authority manipulates the exchange rate through changes in reserves, or in other words through its (partial) commitment to exchange foreign currency for domestic. Plugging equation (17) into equation (16) for the cases where $\rho_{h}>0$, we get:

$$
\frac{H_{t}}{H_{t-1}}=\left(\frac{b_{t}^{c}}{b_{t-1}^{c}}\right)^{1-\rho_{s}}
$$

The equation highlights the extent to which increases in money demand lead to changes in foreign reserves. When the exchange rate is fixed, the money supply changes only through reserves. Under a pure float, the money supply is fixed (we thus implicitly assume no helicopter drop money creation,

foreign cash and other securities, but our analysis can easily be extended to take into account a more general foreign reserve composition. 
i.e. $\left.D_{t}=D_{t-1}\right)$.

\subsection{Equilibrium}

To ensure the existence of a well-defined steady state in small open economy models, the literature has used various short-cuts, summarized in Schmitt-Grohé and Uribe (2003). These shortcuts essentially amount to selecting a level for the steady state NFA and specifying a (reduced form) mechanism driving the economy towards this long-run value. We follow the literature in allowing for a debt-dependent interest rate, but we use a more general functional form that allows for asymmetry between debt and assets, and a de facto upper limit to foreign borrowing. More precisely, we assume that the interest rate on foreign currency bonds is given by:

$$
\log R_{t}=-\log \beta+\nu \frac{e^{-\zeta\left(b_{t} / Y_{t}-\bar{b} / \bar{Y}\right)}-\zeta\left(b_{t} / Y_{t}-\bar{b} / \bar{Y}\right)-1}{\zeta^{2}}
$$

where the last term is a modified Linex function (see Fahr and Smets, 2010 for details), and $Y_{t}=$ $\left(P_{t}^{X} / S_{t}\right) Y_{t}^{X}+\left(P_{t}^{N} / S_{t}\right) Y_{t}^{N}$ is GDP measured in foreign currency. Figure 3 shows the properties of this specification relative to the standard exponential function used by Schmitt-Grohé and Uribe (2003). The loglinear approximation of the linex function yields a standard debt elasticity of $\frac{2 \nu}{\zeta}$.

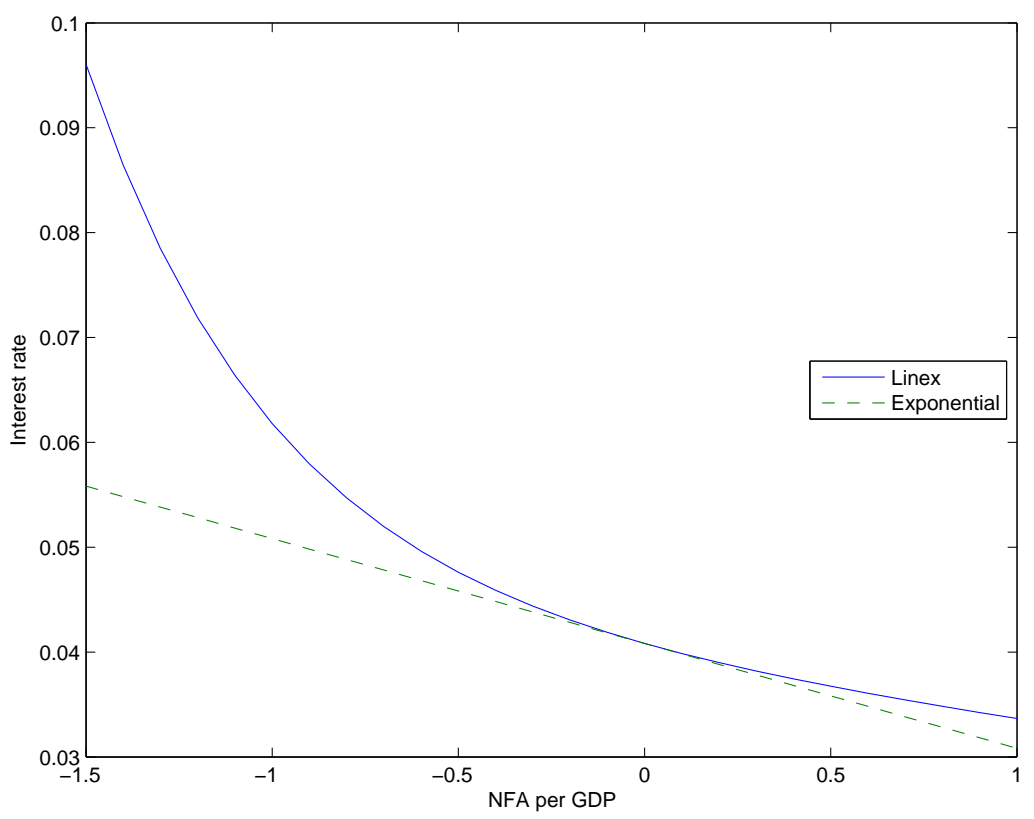

Figure 3: The linex function

The important feature of the Linex specification is that it captures three key aspects of the interest 
premium : (i) (almost) constant interest rate on assets, (iii) quickly rising premium for large debt, and (iii) (almost) existence of an absolute borrowing constraint. Although (i) and (iii) do not hold exactly, one can get arbitrarily close while preserving the smoothness of the premium function by increasing the parameter $\zeta$.

Note that the interest rate depends on foreign debt incurred by households. ${ }^{7}$ In particular, we do not consolidate $b_{t}$ with central bank reserves $b_{t}^{c}$. The assumption behind this is that reserves are only used for liquidity provision, but not for bailing out households (or the government). Thus the riskiness of the country -- measured by the interest premium -- does not depend on the amount of foreign reserves. As noted before, the results would go through as long as debt and reserves are imperfect substitutes.

Now we specify market clearing conditions for non-tradables, exports and imports. Non-tradable market clearing requires that production equals consumption plus investment:

$$
K_{N, t}^{\alpha_{N}} N_{N, t}^{1-\alpha_{N}}=C_{N, t}+I_{X, t}^{N}+I_{N, t}^{N}
$$

We assume that exporters face a downward sloping demand curve:

$$
Y_{t}^{X}=A\left(\frac{P_{t}^{X}}{S_{t}}\right)^{-\eta}
$$

where demand depends on the foreign price of the good.

To derive the current account from the household budget constraint, we use the condition that $d_{t}=H_{t}-S_{t} b_{t}^{c}=\left(1-\rho_{h}\right) H_{t}$ to get:

$$
\frac{b_{t}}{R_{t}}-b_{t-1}+\rho_{h} \frac{H_{t}-H_{t-1}}{S_{t}}=\frac{P_{t}^{X}}{S_{t}} Y_{t}^{X}-C_{T, t}-i_{T, t}^{T}-i_{N, t}^{T}
$$

Under pure floating $\left(\rho_{s}=1, \rho_{h}=0\right)$, money does not enter the current account, and the model is equivalent with a cashless economy (a "real model") with money determined residually. Based on Benczur and Konya (2013), it is easy to see that in this case the local currency interest rate is fixed at its steady state level. ${ }^{8}$ With a currency board $\left(\rho_{s}=0, \rho_{h}=1\right)$, changes in money demand have to be matched by equivalent changes in central bank reserves. Thus in order to increase (decrease) money

\footnotetext{
${ }^{7}$ In our interpretation and calibration the household sector also includes public debt, and government consumption and investment.

${ }^{8}$ Let us define the local currency interest rate as $R_{t}^{d}=R_{t} S_{t+1} / S_{t}$ using the uncovered interest parity (UIP) condition. Benczúr and Kónya (2011) show that under a flexible exchange rate and a constant money supply, nominal spending $P_{t} C_{t}$ is constant. Combing this, the UIP equation and eq. (9) yields the desired result.
} 
holdings, the country has to run a current account deficit (surplus).

It is illuminating to write down the evolution of net foreign assets, which also includes central bank reserves. To derive the general formula, let $R_{t}^{c}$ indicate the gross interest rate that reserves earn (in our specific case $R_{t}^{c}=1$, as discussed above). Moreover, let $B_{t}=b_{t}+b_{t}^{c}$ denote net foreign assets. Using the household and central bank budget constraints, it is easy to show that the evolution of $B_{t}$ is given by:

$$
B_{t}-R_{t-1} B_{t-1}=T B_{t}-\rho_{h}\left(R_{t-1}-R_{t-1}^{c}\right) \frac{H_{t-1}}{S_{t-1}},
$$

where $T B_{t}$ is the trade balance denominated in foreign currency.

This equation makes it clear that currency mismatch operates through two channels in this framework. First, as long as the central bank earns a lower interest rate on reserves than what households pay on foreign debt, holding money (the domestic currency asset) has a real cost for the economy; moreover, the crisis impacts the economy differently through this channel depending on the currency regime. Second, if reserves $\left(b_{t}^{c}\right)$ and non-reserve foreign debt $\left(-b_{t}\right)$ are not equivalent in their impact on the external interest premium, opposing changes in $b_{t}^{c}$ and $b_{t}$-- which keep $B_{t}$ constant -- will still have a real effect through a change in the interest premium.

In our model both of these channels are operational, since we assume $R_{t}>R_{t}^{c}=1$, and only $b_{t}$ enters the interest premium function. When looking at the impact of the crisis from the angle of currency mismatch, the second channel dominates. Defending the exchange rate allows households to build down domestic savings $\left(H_{t}\right)$, and pay back foreign debt $\left(b_{t}\right)$. This leads to a decrease in central bank reserves and hence there is no immediate improvement in the overall NFA position $\left(B_{t}\right)$. Nevertheless, the foreign interest premium declines, because private indebtedness falls. Allowing the exchange rate to depreciate more, on the other hand, decreases the foreign currency value of domestic assets, and hence makes households less able to draw on domestic savings to pay down their foreign debts.

To sum up, equations (1), (2), (3), (4), (6), (7), (9), (10), (11), (12), (13), (15), (16), (18), (19), (20) and (21) jointly determine the endogenous variables. This is a system of nonlinear difference equations. Since our model is deterministic, we can use DYNARE to get an arbitrarily precise solution without resorting to log-linearization. This is important since our specified interest premium relationship is highly nonlinear; one strength of our approach is that we can keep this nonlinearity in our solution method. 


\section{The experiment}

Now we use our model to understand crucial aspects of the financial crisis of 2008 in our small open economy. As we discussed in the Introduction, the important aspects are (i) an external shock to the interest premium, and (ii) a large temporary decline in export demand.

We set up the experiment to replicate important features of the Hungarian experience. As explained earlier, we present simulations from a deterministic model, where the economy is initially in steady state. There are two shocks that unexpectedly hit the economy: a one-period drop in export demand, and a permanent change in the amount of foreign indebtedness that markets are willing to tolerate. More precisely, we lower the parameter $A$ in equation (20) for one period, and move the steady state NFA per GDP level $\bar{b} / \bar{Y}$ to a higher (less negative) level. Thus we trace out the response of the economy as it moves from the initial steady state to a new steady state with lower indebtedness.

The assumption that Hungary was in steady state before the crisis is of course questionable. Nevertheless, we maintain this assumption partly for technical simplicity, and partly for the difficulties in identifying factors that pushed the country away from steady state before the crisis. Regarding one obvious candidate, the capital stock, Konya (2013) argues that a constant capital-output ratio is a good description of the Hungarian experience between 1996-2009. In other words, Hungarian convergence seems to have been characterized by TFP accumulation, and not capital deepening. At least in this sense our initial steady state assumption is a reasonable one.

The one-period export demand shock is included to match the short-run response of the economy better. Also, one can debate if the change in foreign debt tolerance is really permanent. We use this assumption to substitute for an arbitrary end period, and because we do think the external adjustment needed is here to stay for a long time.

\subsection{Calibration}

Figure 4 plots the 5-year CDS spreads for Hungary and the Czech Republic in the 2008-2011 period. We pick the parameters of the interest premium function (18) based on this figure. In particular, we use Hungarian and Czech CDS spreads before and after the crisis, along with the initial (adjusted) NFA positions to pin down the linex parameters. Note that in our model it is the non-reserve part of the total NFA that enters the interest premium function, so this is the data we use for the calculations. We model the crisis as an exogenous shift in the long-run steady state NFA level, but we keep the two shape 
parameters constant.

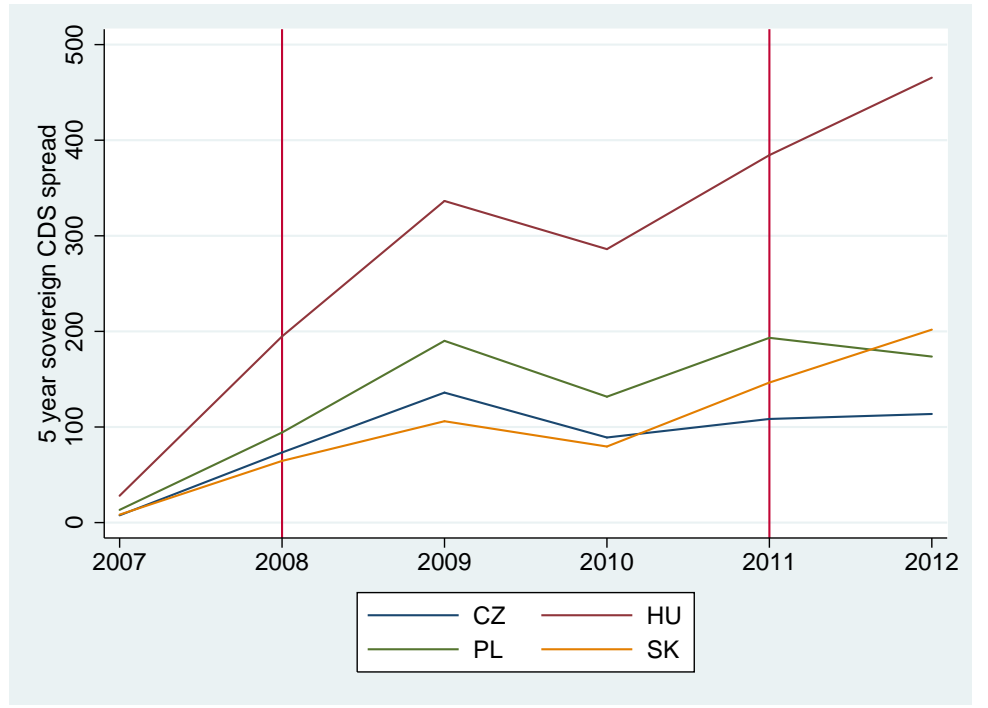

Figure 4: CDS spreads in the Czech Republic, and Hungary

We have 4 parameters to calibrate: 2 shape parameters of the linex function, and $1+1$ location parameters corresponding to the steady state NFA before and after the crisis. We proceed as follows. We assume that the initial level of (nonreserve) NFA in Hungary corresponds to the pre-crisis steady state $\left(\bar{b}_{0} / \bar{y}_{0}=-1.235\right)$, with a constant long-run premium included for both countries (120bp), which is the Hungarian average CDS spread for October 2007 - September 2008 (the year before the crisis). We calculate the maximum increase in CDS spreads for Hungary and the Czech Republic in Q4 2008, before the endogenous response of the NFA levels. We thus have three observations: the increase in spreads in the two countries (HUN: from 120bp to 605bp; CZE: from 35bp to 232bp), and the pre-crisis CDS spread (35bp) at the Czech level of initial indebtedness $\left(b_{0}^{C Z} / y_{0}^{C Z}=-0.58753\right)$. These uniquely pin down the three remaining parameters. Figure 5 illustrates the procedure and the actual calibrated Linex shapes.

The constant debt elasticity approximation of our calibrated linex function yields a slope parameter of $\frac{2 \nu}{\zeta}=0.0138$. Though it is ten times larger than the calibration of Schmitt-Grohe and Uribe (2003), it is also 200 times smaller than the estimate of Garcia-Cicco et al (2010). At the same time, the impact of a 1 percentage point worsening of net foreign assets per GDP on the spread is highly increasing in the starting NFA position: at 0 , the impact is 1.4 basis points, which becomes 6.3 basis points at $-100 \%$ and 16.7 basis points at $-150 \%$.

We normalize the export demand shift parameter in the steady state to $A=1$. We then set the one-period shock to $\Delta A=-0.315$, with which we match the decline in exports (relative to their 1995- 


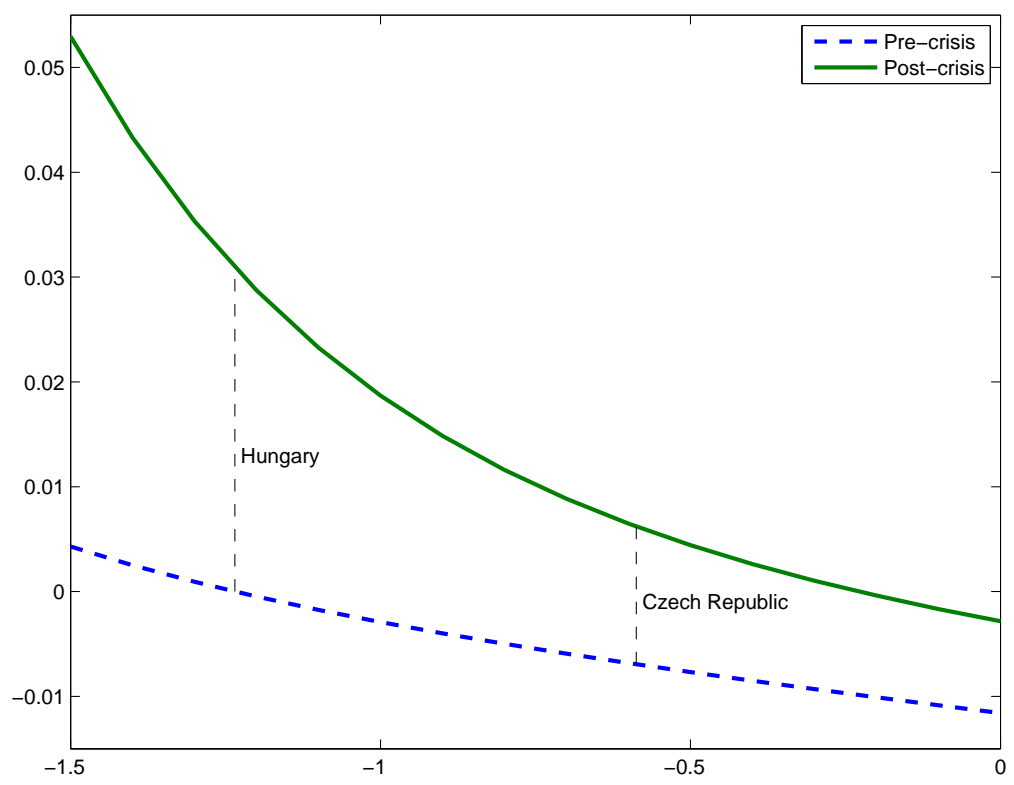

Figure 5: Calibration of the interest premium function

2008, pre-crisis trend). More precisely, since we are interested in the production side, we use domestic tradable production, which is free from inventory dynamics. Note that the parameter change in itself has no meaning, and its only function is to generate an endogenous decline in exports and employment. These, of course, also depend on the elasticity of export demand, and on many other parameters through general equilibrium effects. In particular, the employment response crucially depends on the interaction of exchange rate flexibility and downward nominal wage rigidity. The elasticity of export demand is set to a value that is in line with the estimate of Jakab and Világi (2008). The results are not sensitive to moderate variations in this parameter.

To parametrize the wage adjustment function (14), we use the following considerations. First, we set the symmetric cost parameter to $\nu_{w}=1$, which implies that wage increases are not costly. Second, we pick the asymmetry parameter $\left(\xi_{w}=100\right)$ such that the adjustment function becomes very steep just below $W_{t} / W_{t-1}=0.95$. We do this to take account of the fact that there is neither growth nor inflation in our model. In Hungary, by contrast, the inflation target is $3 \%$ and we postulate that long-run growth is $2 \%$. Thus we shift the floor to wage adjustment by $5 \%$, the hypothesized steady state growth rate of Hungarian nominal wages. The resulting wage cost curve is shown on Figure 9 in the Appendix.

Our remaining parameter choices are summarized in Table 1. In particular, the discount factor is calibrated to yield an annual real interest rate of $4 \%$. The depreciation rate is a standard value in the literature, and corresponds to a steady state investment ratio of about 0.25 in both sectors (inclusive 
of adjustment costs). The shares of tradables in consumption and investment, and the sectoral capital shares, come from Hungarian sectoral national accounts, where we classify sectors A, B C, H and J as tradables (NACE Rev. 2), and the rest of the economy as non-tradables.

The labor supply elasticity is a fairly standard value in the macro literature. Capital adjustment costs are based on Cummins, Hassett and Hubbard (1996) and Cummins, Hassett and Oliner (2006). These papers imply a range of $2-7.5$, of which we take a number close to the midpoint. Steady state labor supply is calibrated to a 0.7 employment rate, with weekly hours of 40 , relative to a total of $7 \cdot 16$. The parameter on money-in-the-utility is calibrated to match the 2001-2008 average Hungarian M2 per GDP ratio (corresponding to the IT regime of the country before the crisis).

\begin{tabular}{lll} 
Parameter & Notation & Value \\
\hline \hline Discount factor & $\beta$ & 0.96 \\
Depreciation & $\delta$ & 0.06 \\
Tradables in C & $\lambda$ & 0.315 \\
Tradables in I & $\lambda_{I}$ & 0.478 \\
Capital share in T & $\alpha_{T}$ & 0.427 \\
Capital share in N & $\alpha_{N}$ & 0.337 \\
Labor supply elasticity & $1 / \omega$ & $1 / 3$ \\
Wage markup & $\frac{\sigma_{w}}{\sigma_{w}-1}$ & 1.4 \\
Capital adjustment cost & $\phi$ & 5 \\
Steady state labor & $\bar{N}(\chi)$ & $0.23(150)$ \\
Steady state M2/Y & $\bar{H} / \bar{Y}(\gamma)$ & $0.48(0.025)$ \\
Monetary policy & $\rho_{s}$ & 0.133 \\
Initial and final reserve ratio & $\rho_{h}$ & $0.452 ; 0.7$ \\
Reserve ratio shock AR coefficient & $\psi$ & 0.55 \\
Export demand elasticity & $-\eta$ & 0.5 \\
Initial and final (non-reserves) NFA position & $\frac{B_{0}}{Y_{0}} ; \overline{\bar{B}}$ & $-1.238 ;-0.228$ \\
Interest premium function & $\nu ; \zeta$ & $0.0145 ; 2.095$ \\
Wage adjustment function & $\nu_{w} ; \xi_{w}$ & $1 ; 100$ \\
Export demand shock & $\Delta A$ & -0.315 \\
\hline
\end{tabular}

Table 1: Calibrated parameters and initial conditions

To describe monetary policy, we need to pin down the reserves to $\mathrm{M} 2$ ratio $\left(\rho_{h}\right)$ before and after the crisis, and the exchange rate flexibility parameter $\rho_{s}$. Hungarian reserves increased substantially during the crisis. We assume this increase was part of the observed policy mix, and model the change as an AR(1) process: $\rho_{h}(t)=\psi \rho_{h}(t-1)+(1-\psi) \bar{\rho}_{h}$. We use Hungarian data between 2008-2012 to roughly pin down the $\operatorname{AR}(1)$ parameter $(\psi=0.55)$ and the new steady state value $\bar{\rho}_{h}=0.7$. Though this value might have been reduced some years after the crisis, for simplicity we assume that the policy shift 
was viewed as sufficiently permanent by all relevant economic actors. The starting value is $\rho_{h}(0)=$ 0.452. The exchange rate flexibility parameter in the policy rule is chosen such that we replicate the FT/EUR depreciation between 2008-2009. It is set to be $\rho_{s}=0.133$.

\subsection{Results}

We plot the results of five simulations. First, we present the baseline case using the calibration we discussed in the previous section. In particular, we set the initial level of non-reserves NFA per GDP to -1.238 , and the monetary policy parameters to $\rho_{s}=0.133$ and $\rho_{h}=0.452$. This, we believe, captures key features of the Hungarian economy when it was hit by the dual shocks to the financing premium and export demand. As explained before, the crises also led to a gradual increase in the money to reserves ratio (to 0.7 ). Our goal in the baseline scenario is to demonstrate that our calibrated model provides a reasonable quantitative description of crisis events, in terms of the size, persistence and sectoral asymmetries of the economy's response.

In addition to the baseline, we explore four counterfactuals. First, we change monetary policy: we explore the cases of a much higher degree of exchange rate flexibility $\left(\rho_{s}=0.28, \rho_{h}=0.452\right)$ and a fixed exchange rate $\left(\rho_{s}=0, \rho_{h}=1\right)$. The first scenario corresponds to a case when there is little monetary defense (the local currency nominal interest rate is raised much less), ${ }^{9}$ while the currency board can also be interpreted as having already been in the Eurozone. Second, we evaluate the impact of the crisis when the initial level of indebtedness is lower, with a starting value of non-reserves NFA per GDP of -0.5875 . This corresponds to the Czech value. It illustrates the counterfactual impact of the crisis on Hungary, had it started from a less negative NFA position (smaller foreign indebtedness).

We are interested in the responses of consumption and employment under these alternative policy arrangements. We expect that a flexible exchange rate smoothes adjustment to the export demand shock, and hence protects employment in the traded sector. This is especially important in the case of downward nominal wage rigidity and a large shock (relative to the $5 \%$ steady state growth rate of nominal wages we assume to be present in the data). On the other hand, because of currency mismatch, a fixed exchange rate protects the balance sheet of households (by allowing a reduction in the risk premium through a decline in local currency assets and private sector foreign indebtedness). Our

\footnotetext{
${ }^{9}$ The main idea is to keep the pre-crisis ratio of reserves to $\mathrm{M} 2$ but allow for more exchange rate flexibility. A much higher $\rho_{s}$ would produce excessive exchange rate depreciation, a huge initial drop in the NFA to GDP ratio, which in turn would prohibit Dynare from being able to solve the nonlinear model. A "true" flexible regime without less (or in particular: zero) reserves would allow for a windfall NFA reduction through the sale of reserves, which we view as an irrelevant policy alternative.
} 
goal is to quantitatively evaluate the strength of these two channels under alternative exchange rate arrangements.

\subsubsection{The baseline}

Figure 6 shows selected variables under the baseline simulation. Our pre-crisis baseline year is 2008 (period zero), and we have data for 2009, 2010 and 2011 after the crisis hit. The stars represent changes we see in the data, relative to their pre-crisis trends (if applicable). The appendix details their definition, sources and the detrending method. Note that the perfect match of the exchange rate and export changes in period 1 is due to our calibration strategy.

Figure 6 demonstrates that the model does a good job matching the impact of the crisis over the first three years, even though other shocks have surely buffeted the Hungarian economy since 2008. The interest rate and exchange rate paths, which are not targeted by our calibration after the first year, are close to the data. The net foreign asset position worsens initially, then begins to improve. While the current account is positive from the first period (not shown), the $12 \%$ devaluation of the exchange rate causes GDP measured in foreign currency to plunge. The NFA stock is denominated in foreign currency, hence the large initial valuation effect we see on the figure. Overall, the magnitude of the changes is quite close to what we observe in the data, although the model overpredicts the NFA change somewhat for the first year.

The initial money stock change in the data is much less than the model's prediction, but over three years the match is much closer. The same is true for the tradable-nontradable relative price. Nominal rigidities in price setting and portfolio reallocation costs may be behind the slower initial response in the data. The intuition the model captures is that households smooth consumption by using their saving as a buffer. In the model, these are in the form of money. In our calibration, we used M2, so the data points on Figure 6 also refer to M2, but there are probably other forms of domestic savings one could take into account. Another possibility is that due to the crisis, households have an increased demand for liquidity (or precautionary savings), which could be modelled as an increase in the parameter $\gamma$.

In terms of real variables, the model is quite successful in capturing both initial changes and further dynamics. Two exceptions include: (i) the much smoother reaction of employment in the data, ${ }^{10}$ which

\footnotetext{
${ }^{10}$ Labor hoarding and government policies (like tax changes) could be partly behind the lack of a large employment drop. A decline in capacity utilization could also be an explanation. There is indeed an approximately $15 \%$ drop in the Eurostat series for Hungarian capacity utilization; which is large but still not sufficient to imply an unchanged employment level. From a growth accounting perspective, we are left with an unexplained drop in TFP.
} 

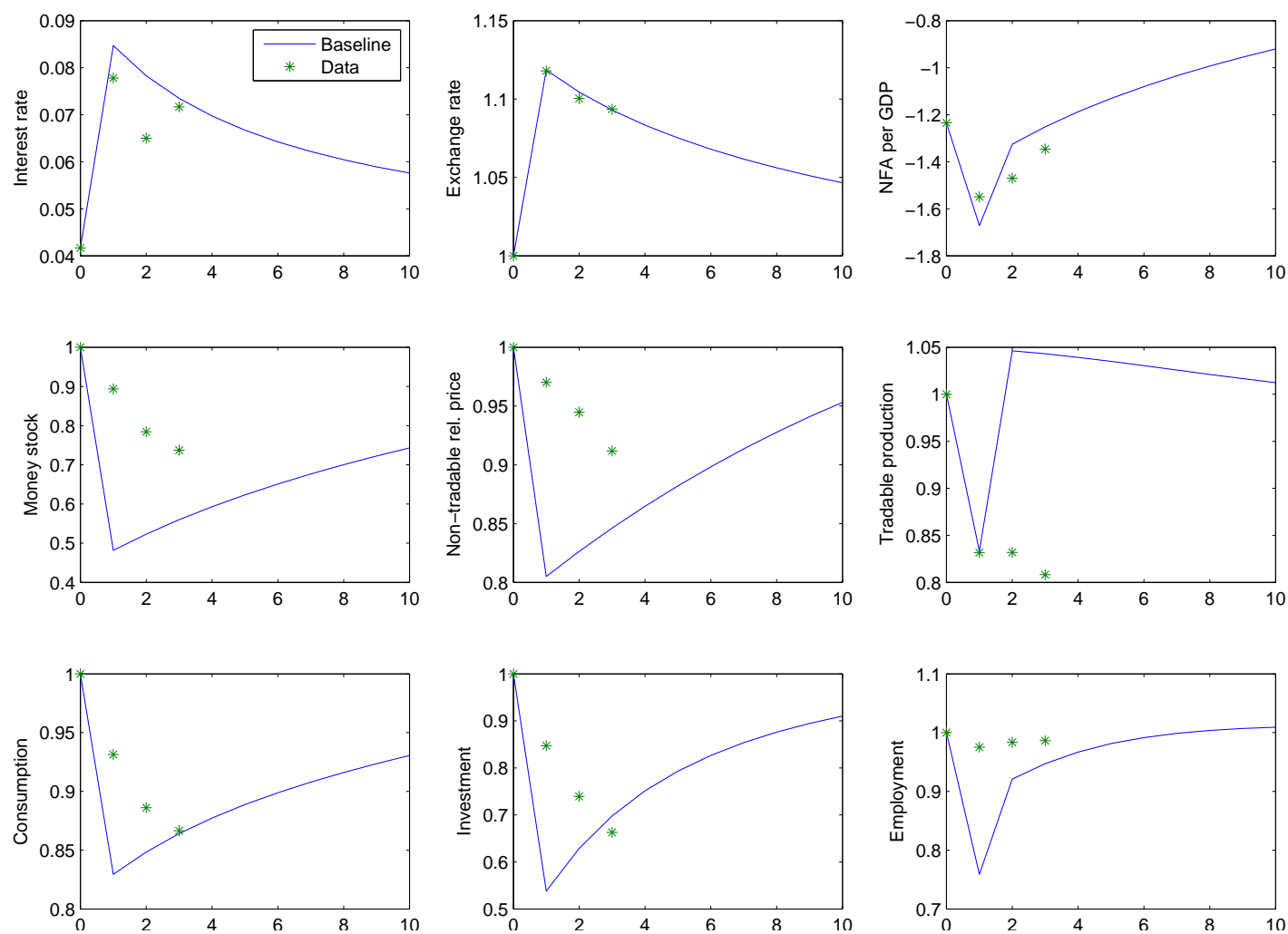

Figure 6: The crisis in Hungary: baseline simulation

is nevertheless reasonably close to the simulated values after the first period, and (ii) the much less pronounced recovery of exports in the data compared to the vigorous export growth predicted by the model. Both issues deserve further investigation.

We experimented with two possible extensions of our baseline model. ${ }^{11}$ First, we added external habit formation in consumption to the utility function, and changed the specification of the capital adjustment cost to an investment adjustment cost. These modifications follow Christiano, Eichenbaum and Evans (2005), and are included to slow down the adjustment of consumption and investment to exogenous shocks. Indeed, with an extra parameter for consumption habits and the investment adjustment cost we can match the evolution of these two variables very well. The fit for other variables, however does not improve, and in some cases (the money stock and the relative price of imports) it worsens somewhat. Since our primary interest is not to match the short-run dynamics of consumption and investment, and the baseline does quite well over our three-year horizon, we decided against these changes. Moreover, micro evidence for external habit formation and investment adjustment costs is weak (Dynan, 2000 and Groth and Khan, 2010).

\footnotetext{
${ }^{11}$ Detailed results for the two extensions described below are available from the authors upon request.
} 
Second, we tried to capture the persistent decline in tradable production with changes in total factor productivity (TFP). Since our baseline does quite well in matching investment and employment changes, it is an accounting identity that measured TFP must have declined as well. Using sectoral national accounts data from Eurostat, we find that the Solow residual was roughly unchanged for nontradables, but declined dramatically for tradables. Conditional on the short time series the latter change is at the very least highly persistent, and possibly permanent, and even more so relative to the pre-crisis trend.

Surprisingly, incorporating this asymmetric TFP decline into the model does not improve the overall fit. While by design we do better with tradable production, the model does much worse in matching consumption and investment changes. We conjecture that the Solow residual is likely to be a poor proxy for true changes in productivity, due to changes in capacity utilization, market power, returns to scale etc. We think that incorporating the many factors that potentially influence observed TFP would unnecessarily complicate the model, which in its simpler form does quite well for most of our target variables. Thus, while viewing it as an interesting research area, we do not pursue this direction further.

Overall, while not perfect, we judge the model's ability to fit key macroeconomic variables to be very good. All variables move in the expected direction, and the magnitudes are also reasonable. Our results are also comparable to those of Heer and Schubert (2012). Their permanent risk premium shock implies a shift of 0.3 in the steady state NFA per GDP position, causing a 250 basis point jump in the interest rate (on impact). In response, consumption drops by $7 \%$, and the real exchange rate depreciates by $3 \%$. In our model, the impact of the pure risk premium shock is 300 basis point jump in the interest rate, ${ }^{12}$ leading to an $12.5 \%$ drop in consumption, and a roughly $6 \%$ real depreciation ( $10 \%$ change in the relative price, and an approximately $60 \%$ non-traded share in expenditures).

\subsubsection{Counterfactuals}

Figure 7 presents the results from the first set of counterfactual simulations. The solid lines are the baseline described above, the lines with squares represent the fixed exchange rate case, and the lines with circles correspond to the more flexible exchange rate case. Under higher flexibility $\left(\rho_{s}=0.28, \rho_{h}=\right.$ 0.452 ), the exchange rate depreciates by more than $25 \%$, and as a result, both the interest premium (not shown) and the NFA per GDP positions worsen dramatically. Note that the local currency (HUF) interest

\footnotetext{
${ }^{12}$ The shock itself is 485 basis points. After the endogenous response of all variables, the interest rate increases by 300 basis points. The (adjusted) steady state NFA per GDP position shifts by 1.01 .
} 
rate only increases slightly, due to the assumption on monetary policy. ${ }^{13}$ The consumption decline is the largest under this scenario, especially from the second period onwards. Tradable production and overall employment, on the other hand, decline the least. Thus our model is capable to generate both the advantages and the disadvantages of a competitive depreciation. The export sector declines less
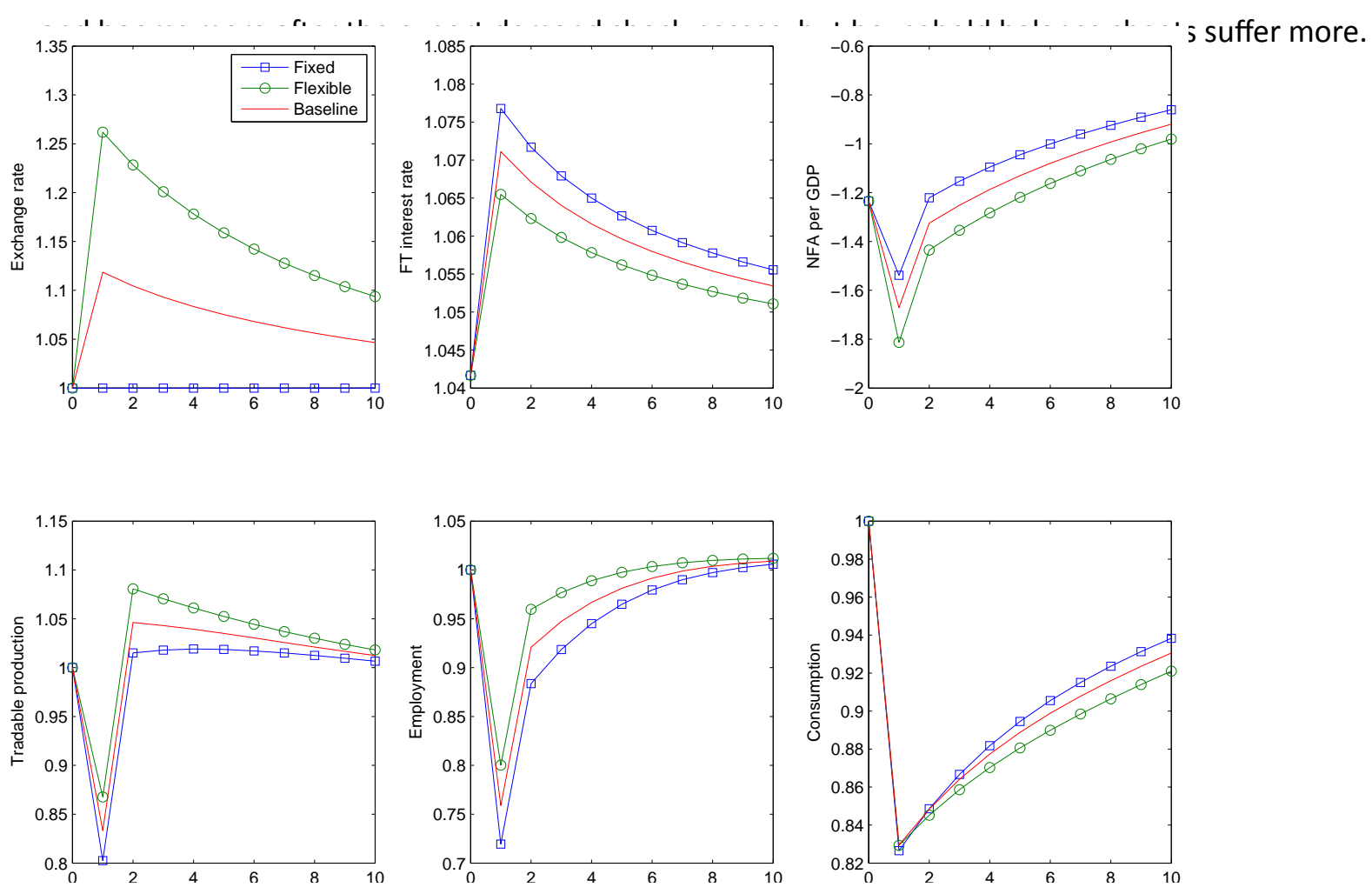

Figure 7: The effects of the crisis: counterfactuals

Fixing the exchange rate protects households from the impact of the currency mismatch, but at the cost of a deeper drop in exports. Consumption recovers the fastest under this regime, but the recession -- in terms of employment -- is the deepest. We can also see that keeping the exchange rate fixed requires a substantial increase in the local currency interest rate (interestingly, our baseline increase was 300 basis points, which coincides with the actual interest rate hike in October 2008). Welfare implications should be drawn cautiously, since employment in itself is actually undesirable in our representative household framework. In a more realistic setup with heterogeneity, the employment decline may lead to a steep income and consumption loss for particular households.

Overall, we conclude that given the high level of indebtedness and currency mismatch, letting the

\footnotetext{
${ }^{13}$ This exercise shows that there is a close mapping between our formulation of monetary policy (exchange rate smoothing) and a monetary reaction function responding to changes in the foreign currency premium.
} 
exchange rate float more freely would have been undesirable for the Hungarian economy. Defending the export sector would have come at the cost of a much larger increase in the interest premium, indebtedness, and a much bigger drop in consumption.

In our final exercise we repeat the policy comparison between a fixed and a relatively flexible exchange rate regime, but assuming a lower level of initial indebtedness. We keep the policy parameters as in the previous experiment, but change the initial level of the non-reserve NFA to GDP ratio to -0.5875 . This was the value for the Czech Republic in 2008. Note, however, that we do not do a full recalibration, and continue using Hungarian values for the rest of the parameters. The exercise should be interpreted as a "what if": what would have been the better policy choice for Hungary in 2008 , had its initial level of non-reserve NFA been at the Czech level.
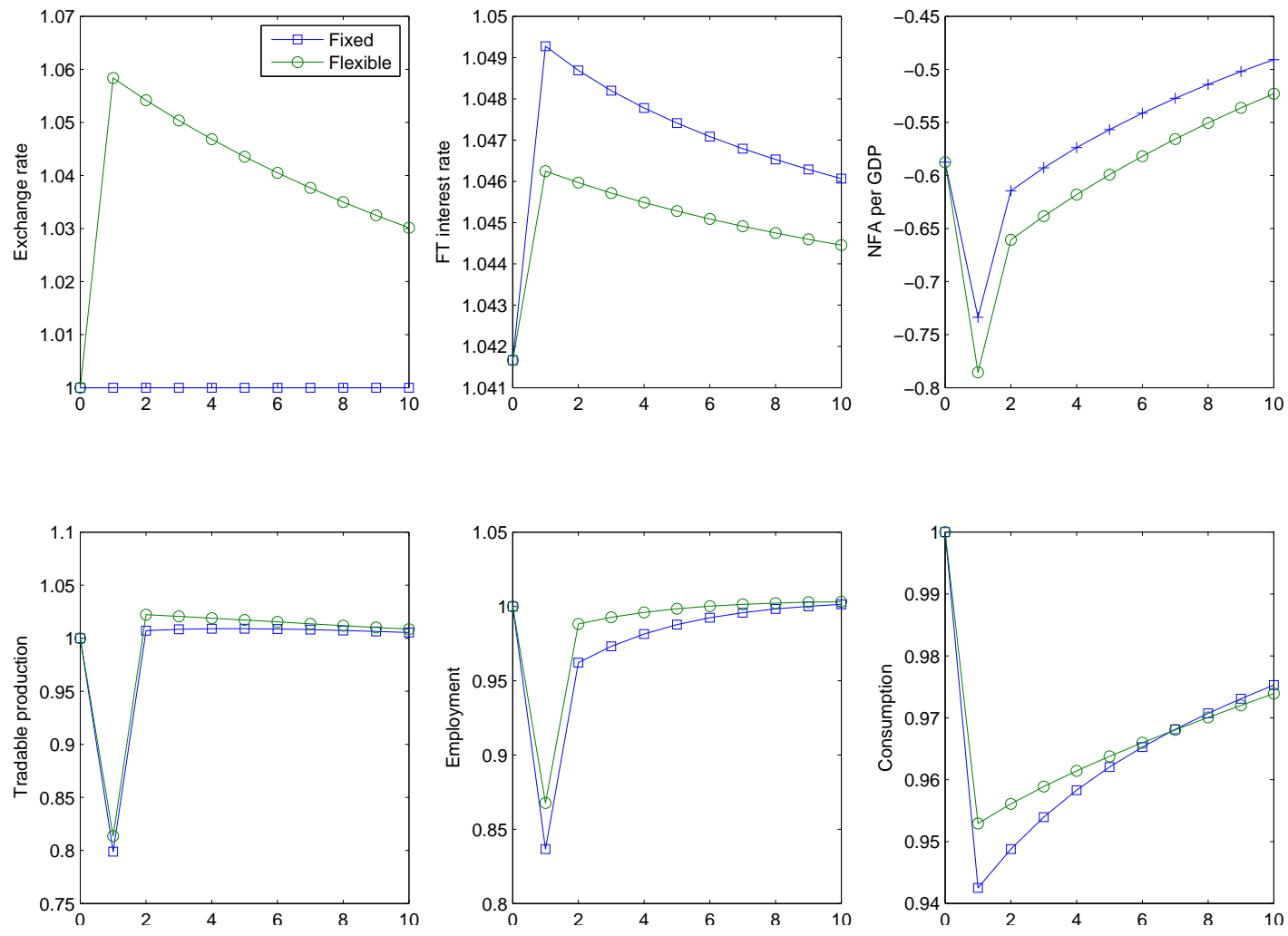

Figure 8: Policy comparison with lower initial indebtedness

Figure 8 presents the results. In general, since the shock is smaller in this case (see also Figure 5), the responses of the endogenous variables are also more muted. Focusing on employment and consumption, however, the policy message is clear. The tradeoff highlighted in the previous experiment disappears. With a lower level of indebtedness, more exchange rate flexibility would have been desirable. In particular, consumption now drops less in the more flexible case. The exchange rate depreciation helps 
with external adjustment, so households can draw down their domestic assets to smooth consumption.

\section{Conclusion}

We presented a simple two-sector small open economy model with a meaningful nominal and external financing side, which we utilized to study the adjustment process of a small open economy to a sudden worsening of external conditions. By adopting a highly non-linear specification of the endogenous external finance premium, we can add credit constraints into a small open economy model in a plausible, quantitatively relevant yet tractable way. This is made possible by the fact that we work in a deterministic framework, and hence we are able to solve the model nonlinearly, even for a highly nonlinear and asymmetric specification for the interest premium function.

We calibrate the model to the performance of the Hungarian economy in the 2000s and its 2008 crisis experience in particular. The main shock we are interested in is a permanent tightening of external credit conditions, implemented as a rise in the foreign interest premium. In order to match the initial developments in these countries, we add a second, one period shock that captures the large drop in foreign demand. Then we also compute four counterfactuals: with two different exchange rate policies (more flexible and a perfect peg), both under the original and a lower level of initial external indebtedness.

Overall, we judge the model's ability to fit key macroeconomic variables to be very good: all variables move in the expected direction, and the magnitudes are reasonable. Our model also generates a quantitatively meaningful tradeoff between letting the currency depreciate and allowing for a quicker real adjustment of the economy, versus protecting consumption expenditures by limiting exchange rate movements and saving household balance sheets.

\section{References}

Bems, R. and K. J. Hartelius (2006). "Trade Deficits in the Baltic States: How Long will the Party Last?". Review of Economic Dynamics, 9: 179-209.

Benczúr, P. and I. Kónya (2013). “Convergence, Capital Accumulation and the Nominal Exchange Rate.” Journal of International Money and Finance, 33: 260-281. 
Brzoza-Brzezina, M., and K. Makarski (2011). "Credit crunch in a small open economy." Journal of International Monetary and Finance, 30: 1406-1428.

Burstein, A., M. Eichenbaum and S. Rebelo (2007). “Modeling Exchange Rate Passthrough After Large Devaluations." Journal of Monetary Economics, 54: 346-368.

Christiano, L., M. Eichenbaum and C. Evans (2005). "Nominal Rigidities and the Dynamic Effects of a Shock to Monetary Policy." Journal of Political Economy, 113: 1-45.

Cook, D. and M. B. Devereux (2006). "Accounting for the East Asian Crisis: A Quantitative Model of Capital Outflows in Small Open Economies." Journal of Money, Credit, and Banking, 38: 721-749.

Cummins, J. G., K. A. Hassett and R. G. Hubbard (1996). "Tax Reforms and Investment: A Cross-country Comparison." Journal of Public Economics, 62: 237-273.

Cummins, J. G., K. A. Hassett and S. D. Oliner (2006). “Investment Behavior, Observable Expectations, and Internal Funds." American Economic Review, 96: 796-810.

Devereux, M. B. and J. Yetman (2010). "Leverage Constraints and the International Transmission of Shocks." Journal of Money, Credit and Banking, 42: 71-105.

De Wind, J. (2008)."Punishment Functions." M.Phil thesis, University of Amsterdam.

Den Haan, W.J., and T. S. Ocaktan (2009). "Solving Dynamic Models with Heterogeneous Agents and Aggregate Uncertainty with Dynare or Dynare++." London School of Economics, Mimeo.

Dynan, K. (2000). "Habit Formation in Consumer Preferences: Evidence from Panel Data." American Economic Review, 90: 391-406.

Erceg, C., D. Henderson and A. Levin (2000). "Optimal monetary policy with staggered wage and price contracts," Journal of Monetary Economics, 46: 281-313.

Fahr, S. and F. Smets (2010). "Downward Wage Rigidities and Optimal Monetary Policy in a Monetary Union." Scandinavian Journal of Economics, 112: 812-840.

Faia, E. (2009). "Financial Frictions and The Choice of Exchange Rate Regimes." Economic Inquiry, 48: 965-982. 
Fernandez de Cordoba, G. and T. Kehoe (2000). "Capital Flows and Real Exchange Rate Fluctuations Following Spain's Entry into the European Community." Journal of International Economics, 51: 49-78. García-Cicco, J., Pancrazi, R., and Uribe, M. (2010). “Real Business Cycles in Emerging Countries?” American Economic Review, 100: 2510-2531.

Gereben A., F. Karvalits and Z. Kocsis (2011). "Monetary policy challenges during the crisis in a small open dollarised economy: the case of Hungary." BIS Papers chapters, in: Bank for International Settlements (ed.), Capital flows, commodity price movements and foreign exchange intervention, 57: 179188.

Gertler, M., S. Gilchrist and F. M. Natalucci (2007). “External Constraints on Monetary Policy and the Financial Accelerator." Journal of Money, Credit and Banking, 39: 295-330.

Groth, C. and H. Khan (2010). "Investment adjustment costs: an empirical assessment." Journal of Money, Credit and Banking, 42: 1469-1494.

Heer, B. and S. F. Schubert (2012). “Unemployment and Debt Dynamics in a Highly Indebted Small Open Economy." Journal of International Monetary and Finance, 31: 1392-1413.

Jakab, Z. and B. Világi (2008) "An estimated DSGE model of the Hungarian economy." Magyar Nemzeti Bank, Working Paper 2008/9.

Judd, K. L. (1998). "Numerical Methods in Economics." The MIT Press, Cambridge, Massachusetts.

Kónya, I. (2013). "Development Accounting with Wedges: the Experience of Six European Countries." The B.E. Journal of Macroeconomics, 13: 245-286.

Lane, P.R. and Milesi-Ferretti, G.M. (2007). "The external wealth of nations mark II: Revised and extended estimates of foreign assets and liabilities, 1970-2004." Journal of International Economics, 73: $223-250$.

Mendoza, E. G. (2010). "Sudden Stops, Financial Crises and Leverage." American Economic Review, 100: 1941-66.

Rebelo, S. and C. A. Végh (1995). "Real Effects of Exchange-Rate Based Stabilization: An Analysis of Competing Theories." NBER Macroeconomics Annual, 125-189. 
Schmitt-Grohé, S. and M. Uribe (2003). “Closing Small Open Economy Models." Journal of International Economics, 61: 163-185.

Végh, C. A. (2013). "Open Economy Macroeconomics in Developing Countries." The MIT Press, Cambridge, Massachusetts. 


\section{Appendix}

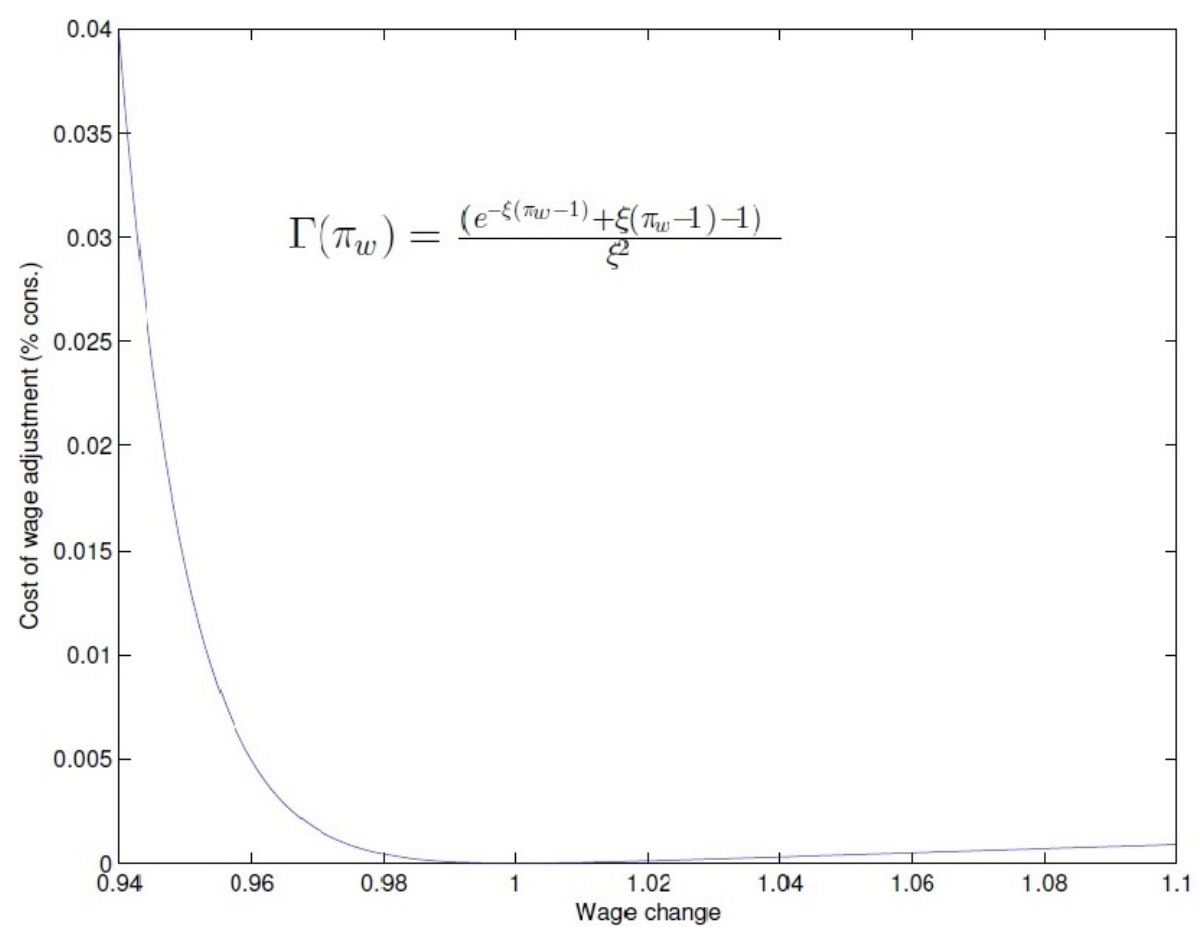

Figure 9: Wage adjustment cost

\begin{tabular}{llll} 
series name & definition & source & adjustment \\
\hline \hline Interest rate & CDS spread plus benchmark rate & Bloomberg & Q3 to Q3 \\
$\begin{array}{l}\text { Exchange rate } \\
\text { NFA per GDP }\end{array}$ & Annual average & MNB & Q3 to Q3 \\
& NFA minus reserves, over GDP (all in & MNB (both NFA and & None \\
Money stock & HUF) & Meserves); Eurostat (GDP) & \\
NT-T relative price & Market services to manufacturing & MNB & Rel. to the 1995-2008 trend \\
Tradable production & $\begin{array}{l}\text { Gross value added, chain-linked } \\
\text { volumes, NACE Rev. 2. sectors A-C, H, J }\end{array}$ & Eurostat & Rel. to the 1995-2008 trend \\
Consumption & Sum of private and government & Eurostat & Rel. to the 1995-2008 trend \\
consumption, chain-linked volumes & & Rel. to the 1995-2008 trend \\
Investment & $\begin{array}{l}\text { Gross fixed capital formation, } \\
\text { chain-linked volumes }\end{array}$ & Eurostat & Rel. to the 1995-2008 trend \\
Employment & Empl. in resident production units & Eurostat & Rel. to the 1995-2008 trend \\
\hline
\end{tabular}

Notes. (1) We assume that without the crisis, the last six variables in Table 2 would have continued their pre-crisis trends; while the first three (interest rate, exchange rate and NFA per GDP) would have remained constant.

(2) The crisis hit right after the end of the third quarter in 2008. Since the interest rate and the exchange rate adjusted immediately, we took their pre-crisis values as corresponding to Q3 of 2008, and all the consecutive years as Q3-to-Q3. For the other variables, adjustment is more gradual, hence this is not a major issue.

Table 2: Data used in Figure 6 